\title{
The Relationship between Work and Home: Examination of White and Blue-Collar Generational Differences in a Large U.S. Organization
}

\author{
Sarah Y. Moore1, Leon Grunberg², Alan J. Krause ${ }^{3}$ \\ ${ }^{1}$ Department of Psychology, University of Puget Sound, Tacoma, WA, USA \\ ${ }^{2}$ Department of Sociology and Anthropology, University of Puget Sound, Tacoma, WA, USA \\ ${ }^{3}$ School of Business and Leadership, University of Puget Sound, Tacoma, WA, USA \\ Email: smoore@pugetsound.edu
}

Received 9 August 2014; revised 5 September 2014; accepted 28 September 2014

Copyright $(2014$ by authors and Scientific Research Publishing Inc.

This work is licensed under the Creative Commons Attribution International License (CC BY). http://creativecommons.org/licenses/by/4.0/

(c) (7) Open Access

\begin{abstract}
The popular press and some practitioner and empirical articles have emphasized work-related generational differences, describing the recent influx of "Gen $Y$ " employees as being less work-centric, more likely to value work and home, and more concerned with achieving work-life balance than "Gen X" or "Baby Boomer" employees. In the current paper, we examine these constructs, focusing on whether such generational differences, if present, extend equally to "white" and "bluecollar" employees. Survey data from 3171 white and blue-collar employees of a large U.S. company revealed that these characterizations were principally found among the white-collar, Gen Y employees. We discuss possible reasons for these findings and question the degree to which generational differences versus workplace experiences shape employee's work-home relationship.
\end{abstract}

Keywords

Generational Differences, Occupational Status, Work-Home Conflict, Work-Home Integration

\section{Introduction}

Much has been written in both the popular press and the empirical literature about the Millennial Generation (those born after 1982) and the new work-related attitudes and expectations they bring to the workplace (e.g., Beutell \& Wittig-Berman, 2008; Costanza, Badget, Fraser, Severt, \& Gade, 2012; DeHauw \& DeVos, 2010; 
Twenge, 2010). Central to the assumption of generational cohort differences is the notion that those born during a particular time period or "zeitgeist" experience similar societal changes and events (e.g., technological advancements, wars) during critical developmental periods. In turn, these societal trends and events shape beliefs, attitudes, and behaviors, imbuing a given cohort with a particular character that differs from previous generations. In this paper, we examine generational differences on one such set of constructs-variables related to the work-home interface-testing whether or not such generational differences are maintained between different occupational groups.

Previous researchers have emphasized several developmental influences that may have affected the workhome expectations the Millennial Generation (also referred to as Generation Y or Gen Y) brings to the workplace. Most notably, these include changes to the psychological contract which defines the implicit relationship between employee and organization (Rousseau, 1989; Rubin, 2012) and the expansion of technology into practically every facet of daily life (Deal, Altman, \& Rogelberg, 2010; Hershatter \& Epstein, 2010). As compared to the Baby Boomer (born between 1946-1964) and Generation X (born between 1965-1981) cohorts, Generation $\mathrm{Y}$ - who have seen their parents affected by wide-spread corporate downsizing, outsourcing, and the dismantling of the previous psychological contract (e.g., Hess \& Jespen, 2009; Ng, Schweitzer, \& Lyons, 2010; Rubin, 2012) that had guaranteed lifetime job security in exchange for commitment and reasonable job performance-are described as being less likely to invest mentally and emotionally in their work. As a consequence, Gen $\mathrm{Y}$ has been characterized as being less work-centric than previous generations; they are more likely to value and prioritize both their work and home lives, to value leisure as well as a meaningful career, and to expect a balance and flexibility between the work and home arenas (Beutell, 2013; DeHauw \& DeVos, 2010; Laff, 2009; Luttrell \& McLean, 2013; Ng et al., 2010; Twenge, 2010).

At the same time, Gen Y employees have grown up as “digital natives” and, although older generations have gained facility with technology, Gen Y has always had the expectation that business transactions and access to information are readily possible at all times, irrespective of location. Because they have grown up, rather than adapted to, the ubiquitous use of technology, they purportedly have greater capacity to multi-task (Hart, 2011; Hershatter \& Epstein, 2010) and are better than previous generations at switching between tasks that vary greatly in both content and skill requirements. Technology, moreover, is the principal mechanism by which one can move seamlessly between the work and home environments. Work is therefore not a place but rather an activity that is not bounded by time of day or setting (Laff, 2009; Luttrell \& McLean, 2013; O’Brien, 2013). In turn, technology is a potentially powerful means by which one can reduce actual conflict between work and home, and Gen Y is ostensibly better positioned to leverage this potential.

Although there are hundreds of articles that focus on the work-home interface, there are relatively few empirical studies that have compared Gen Y workers to other generational cohorts on such variables, both "negative" (e.g., work-to-home and home-to-work conflict or interference), "positive” (e.g., work-to-home and home-towork facilitation, enrichment, or synergy), or "neutral" (e.g., work-centrality, work-to-home and home-to-work integration, work-home balance). In her review of the literature, Twenge (2010) concluded that the three studies employing a time-lag methodology each found that Gen Y expressed a weaker work centrality and a stronger value on leisure than Baby Boomer employees. As another example, Beutell (2013) found that Gen Y employees reported significantly lower levels of work interfering with family than Gen X employees, but for family interfering with work, Gen Y reported higher levels than Baby Boomers. Beutell, however, failed to find significant differences on a measure of work-family synergy, or the degree to which there was a positive spillover from participation in both work and home roles.

Given the importance of this topic, the widespread attention it has garnered in the popular press, and the stereotypic characterization that flavors much of the writing (e.g., Gen Y as a "tech savvy" 24/7/365, highly flexible cohort that is unbounded by time and location), it is surprising that so few studies have systematically examined these assertions, especially in light of the fact that not all jobs afford such autonomy, require the use of technology, or can offer flexibility (Magee, Stefanic, Caputi, \& Iverson, 2012). The reality of many jobs is such that they might require one's presence at the worksite for much or all of the workday, and the degree to which it is possible to use technology to bridge the work-home divide may be quite limited. Beutell (2010) for example found that particular job characteristics (e.g., learning opportunities, job pressure, autonomy) predicted workhome synergy, suggesting that the capacity for such synergy may stem, at least in part, from actual job characteristics. Moreover, others (e.g., Deal et al., 2010; DeHauw \& DeVos, 2010; Real, Mitnick, \& Maloney, 2010) have argued that a college-sampling bias has affected the characterization of Gen Y in previous investigations. 
Previous research, and indeed much of the popular press, has had a professional, "white-collar" bias such that jobs with time-autonomy and/or jobs that rely heavily on technology are over-represented, thereby exaggerating the above distinctions between generational cohorts. Thus, the present study compares three generational cohorts (i.e., Gen Y, Gen X, and Baby Boomer) for employees holding "white” versus "blue-collar" jobs on measures related to the work-home interface. Based on the above review, we posit the following:

H1: As compared to Generation X and Baby Boomer employees, Generation Y employees will report the lowest levels of work emphasis, job involvement, expectations for work-home conflict, and actual work-tohome conflict; they will report the highest expectations for work-home enrichment and satisfaction with integrating work and home.

H2: White versus blue-collar status will interact with generational cohort such that white-collar, Gen Y employees will report the lowest levels of work emphasis, job involvement, expectations for work-home conflict, and actual work-to-home conflict; they will report the highest expectations for work-home enrichment and satisfaction with integrating work and home.

\section{Method}

\subsection{Participants and Procedures}

3665 workers who are employed by a large manufacturing company on the West Coast of the United States participated in this study. Many of the employees at the company are represented by one of two unions, and it was through the union's email lists-approximately 8000 (principally a "white-collar" union comprised of professional and technical workers) and 20,881 (principally a "blue-collar" union comprised of production workers) that employees were invited via email to participate in an anonymous, on-line survey related to work attitudes and experiences. They were told that it would take around 15 minutes to complete, and, based on the recommendation of the unions, workers were not offered any compensation for their participation. Instead, our initial email invitation stressed the ways in which our previous research had been useful to workers, the potential utility of the findings, and our independence from the company. This invitation contained a URL that linked them directly to the survey: one week later, workers received a reminder email that reiterated this same information. Because the unions have promised their memberships that they will not share home email addresses, union leaders distributed the email for us: the survey was constructed such that only one completed survey was received from a given IP address.

We obtained responses from 2284 participants belonging to the blue-collar union (11\% response rate) and 1129 belonging to the white-collar union (approximate 14\% response rate). Some 252 did not answer this question or stated that they did not belong to a union. Although many academic studies report higher survey response rates, in studies that share some of the characteristics of our survey (e.g., longer email surveys to employees), we found response rates as low as .1\% (Crouch, Robinson, \& Pitts, 2011). Based, however, on other research that is similar to ours, such as Rao and Pennington's (Rao \& Pennington, 2013) response rate of $11.2 \%$, and on guidance from professional survey companies, who advise clients to expect large surveys to generate a response rate of $10 \%$ - 20\% (Constant Contact, 2013), we expected our response rate to fall between $10 \%-20 \%$.

The percent of men and women in our sample (see Table 1) was nearly identical to the percentages found in the unions. Age distributions in our sample were likewise very close to the age distributions in each union. Using pay code information from the respondents, we categorized each as being either "white-collar" or "blue-collar.” Consistent with previous research (Lester, Standifer, Schultz, \& Windsor, 2012; Twenge, Campbell, \& Freeman, 2012), we also classified each respondent as belonging either to the Gen Y (born in 1982 or afterward), Gen X (born between 1965 and 1981), or Baby Boomer (born between 1946 and 1964) generation. After removing participants who were born before 1946 or who failed to provide their age, this process yielded the following subsamples: White-collar Gen Y ( $\mathrm{n}=166)$; white-collar Gen X $(\mathrm{n}=235)$; white-collar Baby Boomer (n = 537); blue-collar Gen Y ( $\mathrm{n}=196)$; blue-collar Gen X ( $=609)$; and blue-collar Baby Boomer ( $\mathrm{n}=1428)$.

\subsection{Materials}

The on-line survey contained a series close-ended demographic questions and items related to the topics of workplace attitudes, experiences, and intentions. All measures used in this paper and reported below were drawn from the literature and validated in other studies: scale means, standard deviations, and Cronbach alpha estimates may be found in Table 1. 
Table 1. Descriptive statistics and intercorrelations for measures.

\begin{tabular}{|c|c|c|c|c|c|c|c|c|c|c|c|c|c|c|c|}
\hline Variable & $\% \bar{x}$ & SD & 1 & 2 & 3 & 4 & 5 & 6 & 7 & 8 & 9 & 10 & 11 & 12 & 13 \\
\hline $\begin{array}{l}\text { 1. Gender } \\
\text { ( } 0=\text { male, } 1=\text { female })\end{array}$ & $84.4 \%$ male & - & - & & & & & & & & & & & & \\
\hline $\begin{array}{l}\text { 2. Partner } \\
(0=\text { no partner, } 1=\text { partner })\end{array}$ & 72.7\% partner & - & -.12 & - & & & & & & & & & & & \\
\hline 3. Educational Level ${ }^{\mathrm{a}}$ & 3.88 & 1.45 & .02 & .01 & - & & & & & & & & & & \\
\hline 4. Work hours at work ${ }^{\mathrm{b}}$ & 1.18 & .61 & -.06 & .04 & -.14 & & & & & & & & & & \\
\hline $\begin{array}{l}\text { 5. Work at home } \\
(0=\text { none, } \\
1=1 \text { or more hours/week) }\end{array}$ & $82.1 \%$ none & - & .01 & .05 & .29 & -.08 & - & & & & & & & & \\
\hline $\begin{array}{l}\text { 6. White/blue collar } \\
\text { ( } 0 \text { = blue-collar, } \\
1 \text { = white-collar })\end{array}$ & $70.0 \%$ blue & - & .01 & .01 & .61 & -.17 & .34 & - & & & & & & & \\
\hline 7. Generation ${ }^{c}$ & 2.51 & .69 & -.02 & .02 & -.08 & -.06 & -.02 & -10 & - & & & & & & \\
\hline 8. Home-work emphasis & 3.45 & 2.16 & -.02 & .03 & .02 & -.15 & -.02 & .03 & .16 & $(.74)$ & & & & & \\
\hline 9. Job involvement & 23.47 & 4.86 & .00 & .00 & .00 & .12 & .16 & .03 & .03 & -.36 & $(.70)$ & & & & \\
\hline 10. WF-conflict expectations & 10.17 & 3.14 & -.04 & .01 & .00 & .13 & .09 & -.03 & -.02 & -.05 & .10 & $(.72)$ & & & \\
\hline $\begin{array}{l}\text { 11. WF-enrichment } \\
\text { expectations }\end{array}$ & 9.96 & 2.16 & .00 & .09 & .02 & .03 & .05 & .03 & -.01 & -.13 & .31 & .07 & $(.62)$ & & \\
\hline 12. Work-home integration & 11.16 & 2.52 & -.03 & .06 & -.03 & -.10 & -.16 & -.03 & .01 & .16 & -.29 & -.50 & -.01 & $(.70)$ & \\
\hline 13. WF-conflict & 4.74 & 1.57 & -.05 & .08 & .03 & .22 & .12 & -.03 & -.03 & -.12 & .07 & .56 & .00 & -.40 & (.85) \\
\hline
\end{tabular}

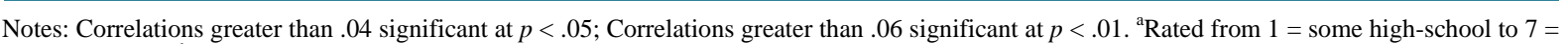
graduate degree; ${ }^{\mathrm{b}} 0$ = less than 40 hours/week, 1 = 40 - 49 hours/week, 2 = 50 - 59 hours/week, 3 = 60 or more hours/week; ${ }^{\mathrm{c}} 1$ = Gen Y, 2 = Gen X, 3 = baby boomer. Internal consistency reliability estimates (alpha) are in the main diagonal.

Home-Work Emphasis. To measure the relative importance of the work versus non-work arenas, we asked seven questions that each began with the stem "Compared to the past, in the last two years have you..." Participants then answered "yes" or "no" to statements such as "devoted more time to your family" or "become more ambitious in your work." Before summing the responses, items were reverse coded such that answers reflective of a greater emphasis toward work received a " 0 ” whereas answers reflective of greater emphasis toward family, leisure, and friends (i.e., non-work) received a “1” (Grunberg, Moore, Greenberg, \& Sikora, 2008).

Job Involvement. We used Lodahl and Kejnar's (Lodahl \& Kejnar, 1965) 8 item measure of job involvement to assess the level of mental preoccupation and work centrality of participants. Using a 5-point response format anchored from "strongly disagree" (1) to "strongly agree” (5), we asked questions such as "I am very much involved personally in my work."

WF-Conflict and WF-Enrichment Expectations. To measure the degree to which employees had workfamily conflict and work-family enrichment expectations, we used a subset of items from the work-family balance scale (Zhang, Yip, Chi, Chan, Cheung, \& Zhang, 2012), modifying the items slightly so that expected conflict or balance was included in each item. The questions asked that participants consider the expectations they have for the relationship between work and home and indicate their agreement with a series of statements using 5-point scale that ranged from "strongly disagree" to "strongly agree." Four items (e.g., Because of my family responsibilities, I expect to have more pressure at work) were summed to create a WF-Conflict Expectations scale, and three items (e.g., Work and family, together, should make my life complete) were summed to create a WF-Enrichment Expectations scale.

Work-Home Integration. To measure respondent's satisfaction with the boundary between work and home, we asked them to consider the interplay between these two areas and indicate whether they "strongly disagreed" (1) or "strongly agreed" (5) with questions such as, "It is often difficult to tell where my work life ends and my family life begins." (Desrochers, Hilton, \& Larwood, 2003). Items were coded and summed such that higher 
scores reflect more satisfaction with work-home integration.

WF-Conflict. Actual work-to-family conflict was measured with a 2-item measures which again asked participants to consider the interplay between their work and home life, followed by the questions, "How often does your... job interfere with your responsibilities at home?” and “... job keep you from spending the amount of time you would like to spend with your family?” Participants indicated their response using a 4-point scale that ranged from “never” (1) to “very often” (4) (Frone, Russell, \& Cooper, 1992).

\section{Results and Discussion}

As we describe in below, and as shown in Table 2 and Figure 1, all significant differences were in the anticipated directions, providing support for both Hypothesis 1 and 2. Descriptive statistics and intercorrelations between the measures are shown in Table 1; point biserial correlations were computed for dichotomously scored

Table 2. ANOVA F-values and estimated means by occupational group and generational cohort.

\begin{tabular}{|c|c|c|c|c|c|c|c|c|}
\hline Variable & & $\begin{array}{l}\text { Gen Y (1) } \\
\text { Mean (SE) }\end{array}$ & $\begin{array}{l}\text { Gen X (2) } \\
\text { Mean (SE) }\end{array}$ & $\begin{array}{c}\text { BB (3) } \\
\text { Mean (SE) }\end{array}$ & $\begin{array}{l}\text { Occp. Mean } \\
\text { (SE) }\end{array}$ & \multicolumn{2}{|c|}{ F-Value (Sig) } & $\begin{array}{l}\text { Direction of Sig } \\
\text { Group Differences }\end{array}$ \\
\hline \multirow{3}{*}{$\begin{array}{l}\text { Home-Work } \\
\text { Emphasis }\end{array}$} & Blue-Collar & $2.77(.17)$ & $3.08(.10)$ & 3.69 (.07) & $3.18(.07)$ & Ocср. & .80 (ns) & \multirow{3}{*}{$1<3,2<3$} \\
\hline & White-Collar & 2.97 (.19) & $3.16(.15)$ & $3.77(.11)$ & $3.30(.09)$ & Gen. & $29.67(.000)$ & \\
\hline & Gen Mean & $2.87(.12)$ & 3.12 (.09) & $3.73(.06)$ & & Int. & .10 (ns) & \\
\hline \multirow{3}{*}{$\begin{array}{c}\text { Job } \\
\text { Involvement }\end{array}$} & Blue-Collar & $23.00(.36)$ & $23.51(.21)$ & 23.38 (.14) & $23.30(.15)$ & Осср. & .18 (ns) & \multirow{3}{*}{$1<2,3$} \\
\hline & White-Collar & 22.71 (.39) & $23.54(.34)$ & $24.01(.24)$ & $23.42(.21)$ & Gen. & $4.19(.015)$ & \\
\hline & Gen Mean & $22.85(.26)$ & 23.53 (.19) & 23.69 (.13) & & Int. & 1.73 (ns) & \\
\hline \multirow{3}{*}{$\begin{array}{l}\text { WF-Conflict } \\
\text { Expectations }\end{array}$} & Blue-Collar & $10.51(.26)$ & $10.83(.15)$ & $10.12(.10)$ & $10.49(.11)$ & Ocср. & $19.29(.000)$ & $\begin{array}{l}\text { BC Higher Conflict } \\
\text { Expectations }\end{array}$ \\
\hline & White-Collar & $9.00(.28)$ & $9.87(.23)$ & $10.00(.16)$ & $9.62(.15)$ & Gen. & $3.73(.028)$ & $1<2$ \\
\hline & Gen Mean & $9.76(.19)$ & 10.35 (.13) & 10.06 (.09) & & Int. & $7.84(.001)$ & $\begin{array}{l}\text { WC Gen Y-Lowest } \\
\text { Conflict Expectations }\end{array}$ \\
\hline \multirow{3}{*}{$\begin{array}{l}\text { WF-Enrich } \\
\text { Expectations }\end{array}$} & Blue-Collar & 9.89 (.18) & $9.93(.10)$ & $9.93(.07)$ & $9.85(.07)$ & Осср. & $4.34(.026)$ & \multirow[t]{3}{*}{$\begin{array}{l}\text { WC Higher Enrich } \\
\text { Expectations }\end{array}$} \\
\hline & White-Collar & 10.30 (.19) & $10.12(.16)$ & $9.98(.11)$ & $10.13(.10)$ & Gen. & .25 (ns) & \\
\hline & Gen Mean & $9.98(.13)$ & $10.03(.09)$ & $9.95(.06)$ & & Int. & 1.99 (ns) & \\
\hline \multirow{3}{*}{$\begin{array}{l}\text { Work-Home } \\
\text { (W-H) } \\
\text { Integration }\end{array}$} & Blue-Collar & $10.83(.20)$ & $10.98(.12)$ & $11.27(.08)$ & $11.03(.08)$ & Осср. & $4.30(.038)$ & \multirow[t]{2}{*}{$\begin{array}{l}\text { WC Most Satisfied } \\
\text { W-H Integration }\end{array}$} \\
\hline & White-Collar & $11.95(.22)$ & 11.03 (.18) & 11.05 (.13) & $11.34(.11)$ & Gen. & 2.37 (ns) & \\
\hline & Gen Mean & 11.39 (.15) & $11.01(.10)$ & $11.16(.07)$ & & Int. & $8.86(.000)$ & $\begin{array}{l}\text { WC Gen Y-Most } \\
\text { Sat W-H Integration }\end{array}$ \\
\hline \multirow{3}{*}{ WF-Conflict } & Blue-Collar & $5.00(.12)$ & $5.11(.07)$ & $4.67(.05)$ & $4.93(.05)$ & Ocср. & $23.49(.000)$ & $\begin{array}{l}\text { BC Higher Conflict, } \\
\text { Actual }\end{array}$ \\
\hline & White-Collar & $4.13(.13)$ & $4.61(.11)$ & $4.68(.08)$ & \multirow[t]{2}{*}{$4.47(.07)$} & Gen. & $4.40(.012)$ & $2>1,3$ \\
\hline & Gen Mean & $4.57(.09)$ & $4.86(.06)$ & $4.68(.04)$ & & Int. & $13.43(.000)$ & $\begin{array}{l}\text { WC Gen Y-Least } \\
\text { WF-Conflict, Actual }\end{array}$ \\
\hline
\end{tabular}

Notes: $\mathrm{BC}=$ blue-collar; $\mathrm{WC}=$ white-collar; Gen. = generation; Occp. = occupational status; Int. = interaction effect. 

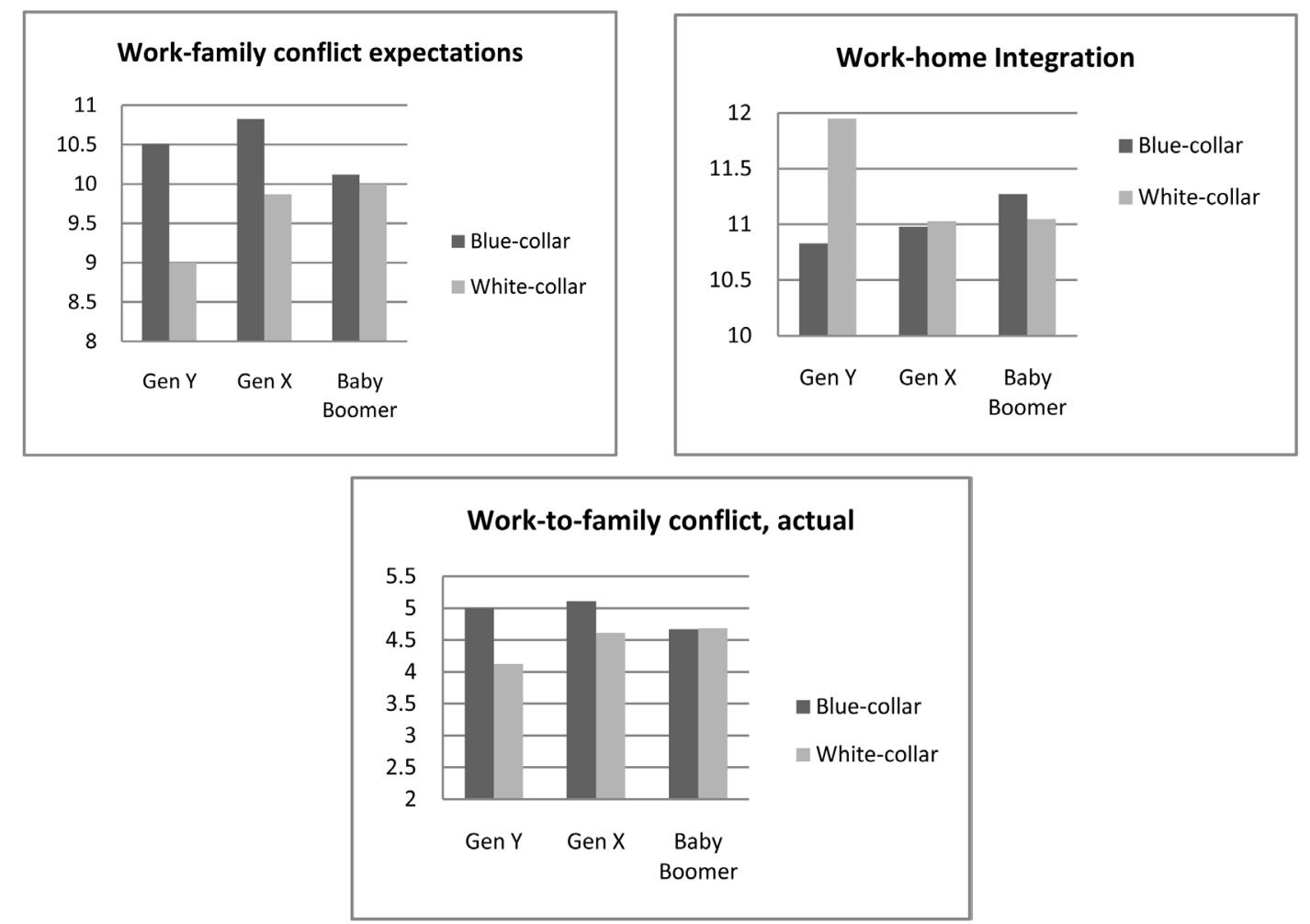

Figure 1. Significant interactions for occupational status by generational cohort.

variables. As reported in other studies (Beutell, 2010; Dilworth \& Kingsbury, 2005; Jain \& Nair, 2013), gender, having a partner, education, and work hours (both those worked at the organization and those worked a home), showed some degree of association with either the independent of dependent variables of interest. We therefore controlled for these demographic variables in all subsequent analyses.

Table 2 presents the 2 (occupational status) * 3 (generational category) ANOVA results and the estimated cell means for generation by occupational grouping as well as their respective estimated marginal means. Significant main effects for occupational grouping were obtained for four of the dependent measures: blue-collar employees reported significantly higher levels of expected WF-conflict and actual WF-conflict, whereas white-collar employees reported significantly higher levels of WF-enrichment expectations and satisfaction with the integration of home and work. As to generational main effects, post-hoc tests revealed that Baby Boomers reported significantly more home rather than work emphasis than did Gen Y or Gen X participants; Gen Y respondents reported significantly lower levels of job involvement than did both Gen X and Baby Boomers; Gen Y respondents reported significantly lower expected WF-conflict than did Gen X participants; and Gen X participants reported significantly higher levels of WF-conflict than did Gen Y or Baby Boomer respondents. Thus, Hypothesis 1 received limited support.

Statistically significant interaction effects were obtained for three of the six dependent variables: expected work-family conflict, work-home integration, and work-to-family conflict. Inspection of the cell means (also shown in Figure 1) reveals support for Hypothesis 2 as we found that white-collar Gen Y employees reported the lowest expected WF-conflict and actual work-to family conflict. They also reported significantly higher satisfaction with their capacity to integrate work and home relative to all other groups. The cell means for both job involvement and WF-enrichment expectations were in the anticipated direction of Hypothesis 2 but failed to reach statistical significance.

As noted by other authors, the interpretation of mean generational differences with cross-sectionally collected data is always confounded with maturation effects (Deal et al., 2010; Twenge, 2010). For example, as compared to Gen X, Gen Y participants may have reported lower levels of work-to-family conflict not so much due to shifting generational attitudes based on common formative experiences but rather due to different stage-of-life demands (e.g., Gen X having to care for children and aging parents simultaneously, Dilworth \& Kingsbury, 
2005). Although we did control for some of the variables that might impact such relationships (e.g., whether or not they were married or had a partner, hours worked at the organization), we were not able to control for more direct impacts on the work-home connection (e.g., presence of children). Furthermore, despite the widespread observations of generational differences in applied settings, the concept of "generational cohort" has received some scrutiny with some scholars taking issue with the practice of using specific cut-off years to define generations (Macky, Gardner, \& Forsyth, 2008), and others highlighting the more salient impacts of familial, educational, or socio-economic influences (Real et al., 2010).

These data limitation noted, the significantly greater emphasis on work rather than non-work coupled with the significantly lower levels of job involvement for all Gen Y employees suggests a potentially interesting shift in Gen Y's approach to work relative to other generations: Gen Y may be comparatively more focused on developing their careers, but they are not as mentally preoccupied and personally defined by their work. Furthermore, given that we found generational differences as a function of white versus blue-collar employee classification, our findings suggest that some of the Gen Y characterizations may be applicable, but only in certain contexts. There are at least two possible reasons for these finding. First, as discussed earlier, white-collar as compared to blue-collar employees may be more likely to use technology that allows for greater time autonomy and location flexibility to complete their work. We did not include measures of autonomy or flexibility in our survey; however, we did ask employees to report the number of days they worked from home in the previous month. Not surprisingly, the main effect for occupational status showed that white-collar workers reported significantly more days worked at home than did blue-collar $(\bar{x}=.99$ vs. $\bar{x}=.52 ; \mathrm{t}[3169]=3.70, p<.001)$. Thus, it may be the case that all Gen Y workers did initially develop generationally different expectations regarding work and home based on widely experienced, common developmental impacts (e.g., being raised as digital natives); such differences, however, have been maintained only in the types of work contexts that support them.

Another possible interpretation is that not all Gen Y workers did, in fact, develop lower levels of work-centrality or expectations for better work-home integration, less conflict, more balance, and more enrichment during their formative years. Instead, it may be that within Gen Y workers, more proximal familial and educational experiences have differentially shaped these expectations, and, as posited by some previous researchers, the oversampling of college-educated students or professional employees has misrepresented the degree to which these particular attitudes extend to the entire cohort. As shown in Table 1, educational status was strongly and significantly correlated with occupational status ( $76 \%$ of white collar workers held at least a 4 year degree versus $11 \%$ of blue collar workers). Thus, although controlling for education does not completely rule out all varying developmental experiences, that we still found significant interaction effects between generational cohort and occupational status-especially with education being so strongly associated with occupational status-points to the potential importance of work characteristics in shaping, differentially by generational cohort, the work-home relationship.

\section{Conclusion}

In conclusion, we do find some limited evidence for generational cohort differences. Although the effect sizes are relatively small (mean $\mathrm{R}^{2}=4.7 \%$ ), the pattern of findings reveals that such differences are more salient among white-collar Gen Y employees: the strong and sweeping stereotypic characterizations found in some of the popular press are not supported by these data. In addition to understanding the basis for such occupational differences, future research could examine the degree to which such generational differences matter in terms of, for example, workplace productivity or attendance as there is varied opinion regarding whether small effect sizes translate into important organizational outcomes (Deal et al., 2010; Twenge, 2010).

\section{References}

Beutell, N. J. (2010). The Causes and Consequences of Work-Family Synergy: An Empirical Study in the United States. International Journal of Management, 27, 650-664.

Beutell, N. J. (2013). Generational Differences in Work-Family Conflict and Synergy. International Journal of Environmental Research and Public Health, 10, 2544-2559. http://dx.doi.org/10.3390/ijerph10062544

Beutell, N. J., \& Wittig-Berman, U. (2008). Work-Family Conflict and Work-Family Synergy for Generation X, Baby Boomers, and Matures: Generational Differences, Predictors, and Satisfaction Outcomes. Journal of Managerial Psychology, 
23, 507-523. http://dx.doi.org/10.1108/02683940810884513

Constant Contact (2013). Frequently Asked Questions: What Is a Normal Survey Response Rate?

Costanza, D. P., Badget, J. M., Fraser, R. L., Severt, J. B., \& Gade, P. A. (2012). Generational Differences in Work-Related Attitudes: A Meta-Analysis. Journal of Business Psychology, 27, 375-394. http://dx.doi.org/10.1007/s10869-012-9259-4

Crouch, S., Robinson, P., \& Pitts, M. (2011). A Comparison of General Practitioner Response Rates to Electronic and Postal Surveys in the Setting of the National STI Prevention Program. Australian and New Zealand Journal of Public Health, 35, 187-189. http://dx.doi.org/10.1111/j.1753-6405.2011.00687.x

Deal, J. J., Altman, D. G., \& Rogelberg, S. G. (2010). Millennials at Work: What We Know and What We Need to Do (If Anything). Journal of Business Psychology, 25, 191-199. http://dx.doi.org/10.1007/s10869-010-9177-2

DeHauw, S., \& DeVos, A. (2010). Millennials’ Career Perspective and Psychology Contract Expectations: Does the Recession Lead to Lowered Expectations? Journal of Business Psychology, 25, 293-302. http://dx.doi.org/10.1007/s10869-010-9162-9

Desrochers, S., Hilton, J. M., \& Larwood, L. (2003). Preliminary Validation of the Work-Family Integration-Blurring Scale. Journal of Family Issues, 26, 442-466. http://dx.doi.org/10.1177/0192513X04272438

Dilworth, J., \& Kingsbury, N. (2005). Home-To-Job Spillover for Generation X, Boomers, and Matures: A Comparison, Journal of Family and Economic Issues, 26, 267-281. http://dx.doi.org/10.1007/s10834-005-3525-9

Frone, M. R., Russell, M., \& Cooper, M. L. (1992). Antecedents and Outcomes of Work-Family Conflict: A Model of the Work-Family Interface. Journal of Applied Psychology, 77, 65-78. http://dx.doi.org/10.1037/0021-9010.77.1.65

Grunberg, L., Moore, S., Greenberg, E., \& Sikora, P. (2008). The Changing Workplace and Its Effects: A Longitudinal Examination of Employee Responses at a Large Company. The Journal of Applied Behavioral Science, 44, 215-236. http://dx.doi.org/10.1177/0021886307312771

Hart, S. (2011). Y Are We Waiting? New Zealand Management, 58, 30-33.

Hershatter, A., \& Epstein, M. (2010). Millennials and the World of Work: An Organization and Management Perspective. Journal of Business and Psychology, 25, 211-223. http://dx.doi.org/10.1007/s10869-010-9160-y

Hess, N., \& Jepsen, D. M. (2009). Career Stage and Generational Differences in Psychological Contracts. Career Development International, 14, 261-283. http://dx.doi.org/10.1108/13620430910966433

Jain, S., \& Nair, S. (2013). Research on Work-Family Balance: A Review. Business Perspectives and Research, 2, 43-58.

Laff, M. (2009). Work Can Wait. $T+D, 63,19$.

Lester, S. W., Standifer, R. L., Schultz, N. J., \& Windsor, J. M. (2012). Actual versus Perceived Generational Differences at Work: An Empirical Examination. Journal of Leadership \& Organizational Studies, 19, 341-354. http://dx.doi.org/10.1177/1548051812442747

Lodahl, T., \& Kejnar, M., (1965). The Definition and Measurement of Job Involvement. Journal of Applied Psychology, 49, 24-33. http://dx.doi.org/10.1037/h0021692

Luttrell, R., \& McLean, D. (2013). A New Generation of Professional: Working with Millennials in 5 Easy Steps. Public Relations Tactics, 20, 15.

Macky, K., Gardner, D., \& Forsyth, S. (2008). Generational Differences at Work: Introduction and Overview. Journal of Managerial Psychology, 23, 857-861. http://dx.doi.org/10.1108/02683940810904358

Magee, C., Stefanic, N., Caputi, P., \& Iverson, D. (2012). The Association between Job Demands/Control and Health in Employed Parents: The Mediating Role of Work-to-Family Interference and Enhancement. Journal of Occupational Health Psychology, 17, 196-205. http://dx.doi.org/10.1037/a0027050

Ng, E. S. W., Schweitzer, L., \& Lyons, S. T. (2010). New Generation, Great Expectations: A Field Study of the Millennial Generation. Journal of Business and Psychology, 25, 281-292. http://dx.doi.org/10.1007/s10869-010-9159-4

O’Brien, K. (2013). Dispelling 4 Ridiculous Myths about GenY Workers. Chicago Tribune, 24 July. http://articles.chicagotribune.com/2013-07-24/business/sns-201307241800--tms--brazenctnbc-c20130724-20130724_1_mi llennials-geny-flexibility

Rao, K., \& Pennington, J. (2013). Should the Third Reminder Be Sent? The Role of Survey Response Timing on Web Survey Results. The Market Research Society, 55, 651-674.

Real, K., Mitnick, A. D., \& Maloney, W. F. (2010). More Similar than Different: Millennials in the U. S. Building Trades. Journal of Business and Psychology, 25, 303-313. http://dx.doi.org/10.1007/s10869-010-9163-8

Rousseau, D. M. (1989). Psychological and Implied Contracts in Organizations. Employee Responsibilities and Rights Journal, 2, 121-139. http://dx.doi.org/10.1007/BF01384942

Rubin, B. A. (2012). Shifting Social Contracts and the Sociological Imagination. Social Forces, 91, 327-346. http://dx.doi.org/10.1093/sf/sos122 
Twenge, J. (2010). A Review of the Empirical Evidence on Generational Differences in Work Attitudes. Journal of Business and Psychology, 25, 201-210. http://dx.doi.org/10.1007/s10869-010-9165-6

Twenge, J. M., Campbell, W. K., \& Freeman, E. C. (2012). Generational Differences in Young Adults’ Life Goals, Concern for Others, and Civic Orientation, 1966-2009. Journal of Personality and Social Psychology, 102, 1045-1062.

http://dx.doi.org/10.1037/a0027408

Zhang, H., Yip, P., Chi, P., Chan, K., Cheung, Y., \& Zhang, X. (2012). Factor Structure and Psychometric Properties of the Work-Family Balance Scale in an Urban Chinese Sample. Social Indicators Research, 105, 409-418. http://dx.doi.org/10.1007/s11205-010-9776-3 
Scientific Research Publishing (SCIRP) is one of the largest Open Access journal publishers. It is currently publishing more than 200 open access, online, peer-reviewed journals covering a wide range of academic disciplines. SCIRP serves the worldwide academic communities and contributes to the progress and application of science with its publication.

Other selected journals from SCIRP are listed as below. Submit your manuscript to us via either submit@scirp.org or Online Submission Portal.
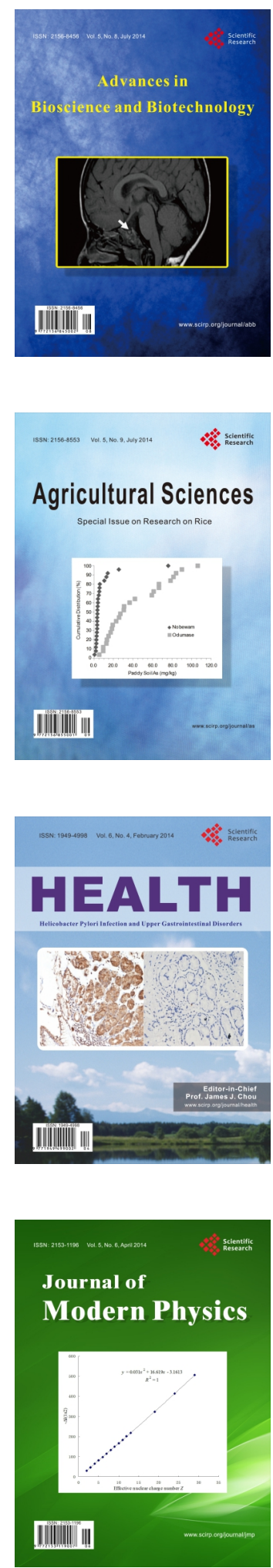
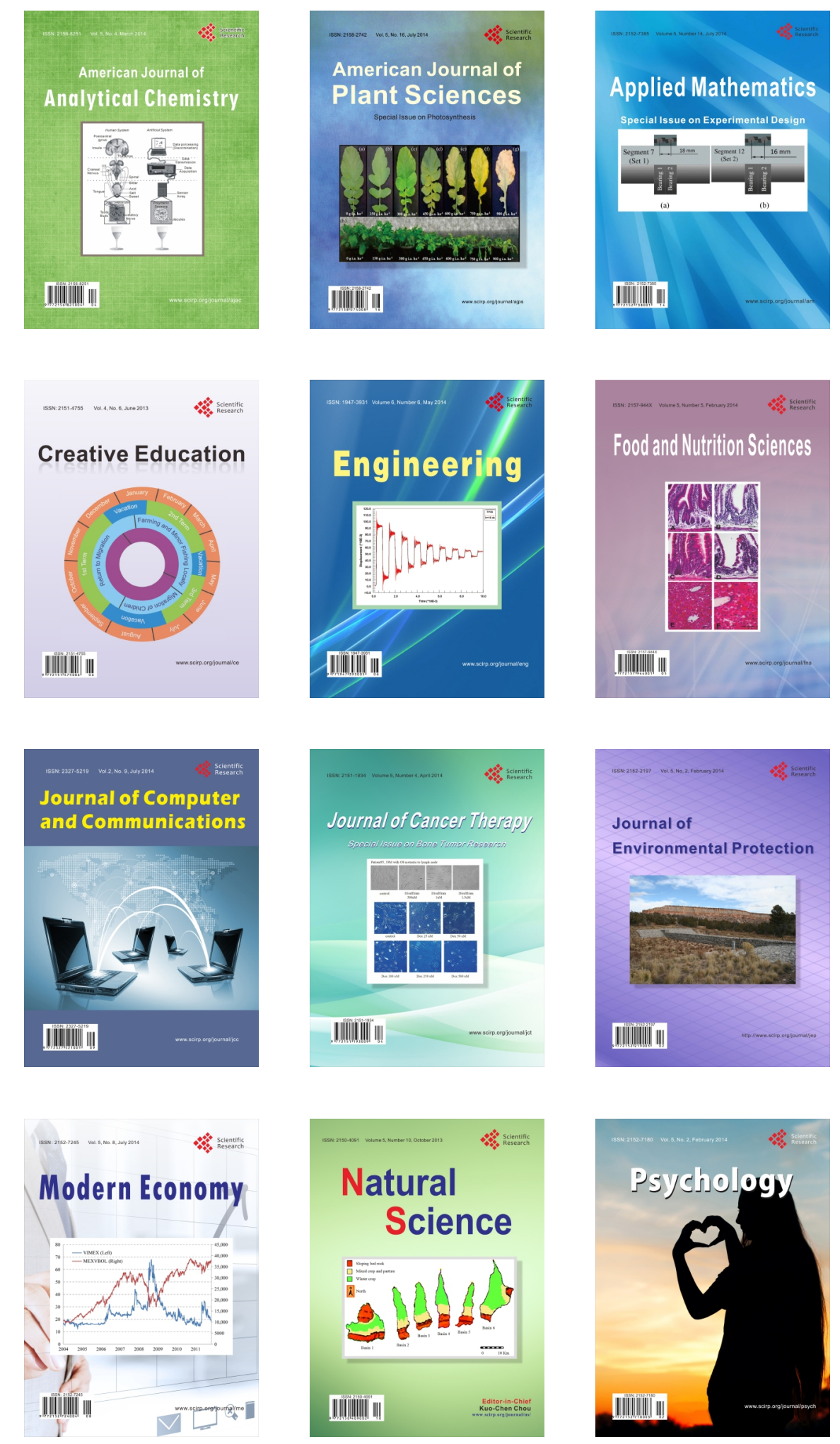